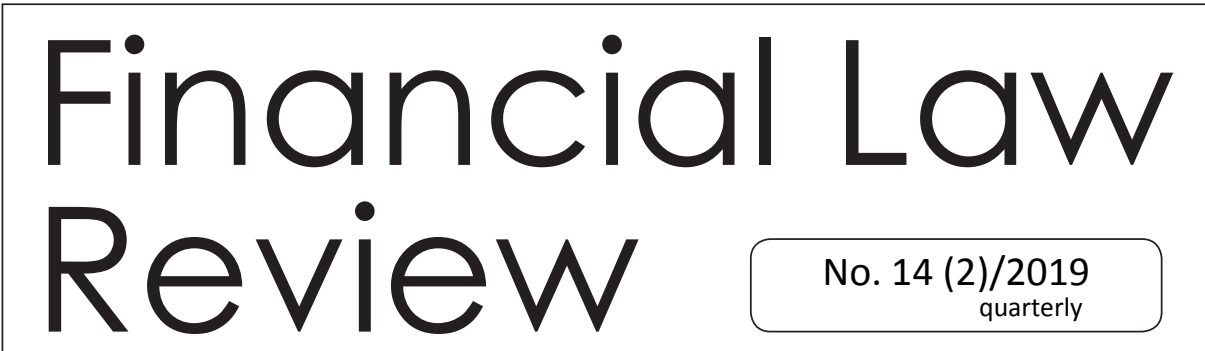

UNIVERSITY OF GDAŃSK • MASARYK UNIVERSITY • PAVEL JOZEF ŠAFÁRIK UNIVERSITY • UNIVERSITY OF VORONEZH http://www.ejournals.eu $\bullet$ http://czasopisma.bg.ug.edu.pl

\title{
THE USE OF DIGITAL TECHNOLOGIES IN THE FINANCIAL ACTIVITIES OF MUNICIPALITIES: THE EXPERIENCE OF RUSSIA AND EUROPEAN COUNTRIES \\ SVETLANA MIRONOVA*
}

\begin{abstract}
The development of information technologies and the adoption of programs in digital economy are aimed at increasing the efficiency of state and municipal government, including in the financial sphere. The article examines the impact of information technology on the financial activities of municipalities both in Russia and in some European countries. The main problems are associated with the legal regulation of financial support of municipalities, such as low level of own revenues of local budgets, dependence on financial assistance from higher budgets, redistribution of powers and financial resources between state authorities and local governments and others. It is shown how the means of informatization affect the increase in the collection of taxes received by the local budget. Examples of using quadcopters to control taxpayers' property are provided, which contributes to an increase in local income. It is concluded that at present only the formation of the legal framework for the introduction of information technologies in the financial activities of municipalities is beginning, and the lack of funds at the municipal
\end{abstract}

* Candidate of juridical sciences, Associate Professor, Department of entrepreneurial and financial and tax law, Volgograd Institute of Management - branch of the RANEPA, Gagarina street, 8, Volgograd, 400131, Russia. Specialist in the field of financial law, research interests - financial and legal status of municipalities. Author of more than 130 publications, including monographs, and textbooks. Member of the Public Chamber of Volgograd. As the Director of the legal clinic, she carries out activities on legal education of various categories of citizens and provides free legal assistance Contact e-mail: smironova2017@gmail.com 
level will not allow the introduction of information technologies in full without state participation.

The author uses the scientific methods of analysis, synthesis, and comparison.

\section{Key words:}

Local self-government, municipalities, local budget revenues, financial support, digital technologies, tax control, tax portal, electronic interaction

JEL Classification: H71, H72, H77

\section{Financing:}

This work was supported by the Volgograd Institute of Management - RANEPA, in the framework of the execution of the scientific project No. 04-2018VIM "Relevant problems of the protection of rights and freedoms in the digital space".

\section{Introduction}

Problems of financial support of municipalities traditionally attract the attention of scientists of financial and legal science both in Russia and in European states, who investigate the relationship between the powers of state authorities and local governments, the financing of delegated powers, ways to increase the financial independence of municipalities, including the expansion of the number of powers of municipalities in the financial sector. The introduction of information technology in state and municipal management allows to solve some of these issues. The aim of the article is to study the formation of the legal regulation of digital economy in Russia and abroad; the impact of the use of information technologies in the implementation of financial activities by municipalities, the increase in revenues of local budgets, as well as the effectiveness of monitoring their collection. The main aim of the contribution is to confirm or disprove the hypothesis that the use of information technology in the implementation of financial activities by municipalities affects the increase of revenues of local budgets. If the hypothesis is confirmed, then the task is to describe and characterize the mechanisms of the influence of information technologies on the collection of revenues to the local budget, as well as the need to monitor their collection.

The scientific methods of analysis, synthesis, and comparison are to be used. 


\section{Financial foundations of local self-government in Russia and European states}

European Charter of Local Self-Government sets out the concept of local selfgovernment. According to Article 9, local authorities shall be entitled to adequate financial resources of their own, of which they may dispose freely within the framework of their powers and part at least of the financial resources of local authorities shall derive from local taxes and charges.

In the Constitutions of states, the right of local self-government bodies to financial independence is assigned. For example, in order to understand basic assumptions that have been adopted during works on the new codification of tax law in the context of local government tax authorities, it should be indicated that pursuant to Art. 167.1 of the Constitution of the Republic of Poland, the principle has been expressed therein according to which local government units shall be assured public funds adequate for the performance of the duties assigned to them (Dowgier, 2017: 126).

Art. 65 par. 2 of the Constitutional Act no. 460/1992 Coll. the Constitution of Slovak Republic declares that municipalities shall fund their needs predominantly with the use of their own revenues, and subsequently from state grants, which leads to the conclusion that to create an independent self-government that is capable of funding its needs and execute its policy by own resources, it is obvious that the funds obtained within the own resources should prevail (Románová, Červená, 2017: 46).

In Russia, on the one hand, the independence of local self-government from state authorities is enshrined in the Constitution of the Russian Federation, including in matters of forming the local budget, establishing local taxes and charges, predetermining the analysis of local budget revenues, identifying hidden reserves for their formation, as well as identifying ways to further improve in this direction. At the same time, among the problems of the legal support of the budget system there is the fact that compliance with and implementation of constitutional guarantees of independence of the constituent entities of the Russian Federation and municipalities are questionable (Paul, Soloweva, 2016).

Despite the consolidation of the principle of financial independence of municipalities in national legislation, in many European countries, including Russia, there is a lack of financial independence of municipalities and their dependence on state budgets (Mironova, 2018; Radvan, 2017; Románová, Červená, 2017). As 
Juchniewicz says "There is no other topic more popular at local finance than fiscal local autonomy or closely related another topic which concerns the issue of revenue sharing between the State and local government units" and "problem of fiscal local autonomy affects every country in which there is local government" (Juchniewicz, 2017: 34-35).

The terms of reference of local governments to establish taxes, the so-called term "tax autonomy" (Juchniewicz, 2017: 36), are limited, and in Russia to a greater extent than in other states (Mironova, 2018; Reut, Soloveva, 2018); as rightly noted, until the municipalities are not able to at least partially influence the amount of tax revenue, there will still be a threat for their autonomous actions. (Radvan, 2017).

In Slovakia the ratio of particular municipality's budgetary revenues clearly shows that genuine own, i.e. local, sources of funding are definitely insufficient (Románová, Červená, 2017: 54). Attention is drawn to the need to increase the collection of non-tax revenues, including business, the use of municipal property (Románová, Červená, 2017: 54; Gliniecka, Mironova, 2019).

Both in Russia and in many European countries, the question of the balance between state administration and local self-government and the delegation of authority remains unresolved. Local government is fundamentally influenced by organization of public sector in the state. This struggle for balance in relation between competences and resources definitely needs a more efficient solution (Románová, Červená, 2017: 54). In addition to solving local issues of their own, municipalities are assigned an excessive number of state powers transferred by higher authorities. As noted in the literature "delegated competence represents an "extended hand" of the state administration" (Kranecov6, Czudek, 2017: 2).

Transferred state authority must be adequately funded, while there are cases when financial security is not enough. For example, in Russia, the allocation of subsidies for the implementation of delegated state powers often does not cover them in fact (Gliniecka, Mironova, 2019: 134).

One of the problems of the financial adequacy of the budgets of municipalities is a high level of municipal debt in some municipalities, as well as the need to properly maintain the budget accounts of municipalities. For example, Skuza proposes to solve this problem in Poland by ensuring consolidation of management of bank accounts of local self-government units within one entity (Bank Gospodarstwa Krajowego) (Skuza, 2017: 59). 
Despite the fact that the disposal of the budget account is an integral element of the ownership of the local budget (Krokhina, 2005), in Russia, the maintenance of budgetary accounts of municipalities is carried out exclusively by the Central Bank of the Russian Federation, which makes the indicated problem less urgent.

Thus, in many states there is an acute question of the financial independence of municipalities, attempts are being made to improve the legal regulation of the financial and legal status of municipalities in order to increase the efficiency of their financial activities. One of the ways of such improvement can be the introduction of information technologies and their use in the implementation of the financial activities of municipalities. Taking into account the fact that recently the digital economy is being introduced all over the world, it is advisable to consider what tools can be used to improve the financial system of municipalities.

\section{Legal regulation of digital economy and the main directions of its development in the financial sector}

As Mariański notes, "the main issue from the point of view of the state is to adapt the legal framework to the new technological possibilities" (Mariański, 2018, 101). The introduction of digital technologies requires appropriate legal regulation, which is now in the process of being formed, since laws do not always keep pace with the rapidly developing technologies.

First of all, strategies and programs on digital economy are adopted at the national level, in which the concept of the regulatory and legal regulation of this sphere is prescribed, as well as the main areas that the government considers to be priorities in digital economy.

For example, France adopted Act of 21 June 2004 for confidence in digital economy (Loi n 2004-575 du 21 juin 2004 pour la confiance dans l'ŭconomie numŭrique). In the UK Digital Economy Act 2017 operates. At the same time, in many states there is no unified concept of legal regulation of informatization, and only certain regulatory acts are in force.

In the Russian Federation, the national program "Digital Economy of the Russian Federation" adopted in December 2018 and replacing the program "Digital Economy of the Russian Federation" 2017 is currently in force. Despite the fact that the municipal level of government, as well as municipal institutions and organizations are mentioned in the program as subjects of introducing digital economy, the program mainly involves its implementation at the federal level. 
At the same time, for it to be implemented at the regional level and at the level of municipalities, programs of regional and municipal levels should be adopted. Such regulations were created only in some regions of the Russian Federation and municipalities (the republics of Bashkortostan, North Ossetia, the Novgorod region, the city of Yakutsk).

Thus, in Russia, for the time being, the standard regulation of digital economy is carried out only at the federal level, separate regulatory acts are being developed at the level of regions and municipalities, but the legal framework has not yet been fully formed. At the same time, the allocation of budget funds for the introduction of information and technologies from the federal budget does not yet extend to support municipalities, since they lack the appropriate legal regulation and municipal programs aimed at introducing digital technologies to solve local issues. At the regional and municipal levels, commissions and coordinating bodies are created for the development of digital economy.

One of the pressing issues is the lack of necessary financial resources for informatization from municipalities. In this regard, it is important to provide funding for programs of digital economy and for implementation in municipalities at the federal level. Russia should study the experience of foreign countries. For example, in Poland there is a list of areas in which local governments can apply for financial support (Mosionek-Schweda, Panfil, 2018: 444).

The introduction of information and digital technologies in financial activities is considered mainly in the banking and foreign exchange sectors, in relation to the introduction of digital technologies in banking operations, electronic payments, etc. (Pastushenko, Zemtsova, 2018; Schweigl, Blahek, 2017; Schlossberger, 2015; Kucherov, 2018; Cyman, 2018).

Legalization of electronic document circulation, equating electronic documents with their paper equivalents at the legislative level allows to expand the interaction of public authorities and local governments with each other. As Mariański notes, "this new definition was a very significant step in the process of adapting the new technologies by the legal framework, also in the field of public and local finances in Poland" (Mariański, 2018: 99).

Digital technologies are being actively introduced in the tax sphere, both from the point of view of the interaction of tax authorities and taxpayers, and in the exercise of tax control. As Teszner notes, "contemporary tax administration aims to make it easier for all taxpayers to voluntarily pay the tax. Computerization of tax 
administration changes its character by balancing the imperious nature instruments used with the service tools offered to taxpayers" (Teszner, 2015:171).

In Russia, quite a lot of attention is paid to the introduction of digital technologies in tax administration and tax control. One of the main goals of the Federal Tax Service of the Russian Federation is to create conditions for the timely and full fulfillment by taxpayers of their obligations to pay taxes and charges, including by providing convenient and reliable ways of information interaction based on modern technologies.

The Order of the Federal Tax Service of Russia dated 13.06.2013 No. MMP-7-6 / 196 approved the Methodological recommendations on the organization of electronic document circulation between tax authorities and taxpayers in the information service and informing taxpayers in electronic form via telecommunication channels. Methodological recommendations determine the order of interaction between the participants of electronic document management, a list of mandatory functions and the frequency of their implementation for each participant, as well as the formats for submitting requests and responses to them.

These measures are designed to streamline the growing electronic document flow between tax authorities and taxpayers. Most businesses and individuals have long appreciated the benefits of taxpayer service through telecommunications channels.

Interdepartmental cooperation of the Federal Tax Service with other government bodies (for example, the customs service), administration of the federal electronic registry office of the civil registry office are among the elements of the work on digitalization of the economy, they create the basis for the formation of the population register, reduce the time required to provide services to citizens in electronic form, which generally contributes to the collection of taxes in Russia (Mikhail Mishustin...).

The main directions of the budget, tax and customs tariff policy for 2019 and for the planned period of 2020 and 2021, approved by Russian Ministry of Finance as measures to reduce the informal sector, plan to continue implementing a set of measures to improve the administration of revenues of the budget system, including an account of the further digitalization of tax administration and the integration of all information sources and data streams into a single information space with the subsequent automation of its analysis based on the introduction of modern large amounts of processing technologies. 


\section{The impact of the introduction of digital technologies to improve the efficiency of financial support of municipalities}

Despite the rapid development of legislation in the field of the digital economy, legal regulation is carried out mainly at the national level, and almost does not affect the digitization of the financial activities of municipalities. Despite the fact that egovernment programs, and interactions between government bodies also concern local governments, in practice, due to the lack of financial resources in municipalities, such technologies are being introduced last. Nevertheless, one cannot but recognize the influence of information technologies on improving the quality of work of municipalities, improving the efficiency of their financial activities.

There are studies in which certain aspects of the implementation of information technologies in the financial activities of municipalities are addressed (Mariański, 2018).

For municipalities, a special role is played by increasing the collection of revenues of local budgets, especially from tax payments. In this regard, it is important to work with taxpayers, both in terms of informing them about tax payments, their tax duties, electronic interaction with tax authorities and local governments (in cases where it is necessary, for example, when registering objects of taxation), obtaining permission to pay the charge, etc.), and in part of the implementation of control over the payment of taxes, both by tax authorities and by state authorities and local governments.

The increase in tax revenues depends on the awareness of taxpayers in general about what taxes should be paid in what time frame, the ability to calculate the amounts of these taxes before they are paid, the receipt of tax returns and reporting forms and the possibility of their filing in electronic form, the possibility of paying tax in electronic form in a simplified manner (for example, through an online bank). Such electronic interaction between the taxpayer and the tax authority contributes to an increase in tax revenues to local budgets.

So, in the Russian Federation, one can find a list of taxes and charges, and basic requirements for their payment on the website of the Federal Tax Service of the Russian Federation, one can also find property tax rates for individuals and land tax by municipalities, calculate the patent value, download the program for filling out a tax declaration on income of individuals in electronic form (https://www.nalog.ru).

Information on local taxes posted on the website of the Federal Tax Service is particularly relevant because not all municipalities have official websites, and if they 
are available they often do not update the information, which makes it difficult for citizens to know what local taxes they should pay. It should be noted that the lack of sufficient funding for municipalities makes it impossible to exercise properly many of the powers vested in local authorities, which is why it is better to leave tax administration to tax authorities rather than delegate it to municipalities as done, for example, in Slovakia (Románová, Červená, 2017: 56). At the same time, in Poland, where municipal tax authorities operate, it is proposed to increase their effective interaction with taxpayers by delivery through the means of electronic communication (Etel, 2018: 383).

Improved tax collection can contribute to the automatic calculation of the taxes. In the literature it is noted that the main problem in introducing the full digitalization and automatic calculation of local taxes is related to big importance of exemptions and reliefs in the local taxation (Mariański, 2018: 102).

Taxpayers can interact with the tax authority through the taxpayer's personal office in which they can see their taxation objects, the accrued tax amount, submit an application, a declaration, etc. Taxes can be paid via the Federal Tax Service website, through the Sberbank and other banks, online banks, through the State Services portal (https://gosuslugi-online.ru/kak-oplatit-nalogi-online-cherez-gosuslugi/).

Poland has an official Tax Portal (https://www.podatki.gov.pl/) which contains information on existing taxes, including local ones. The portal also posted forms of tax returns and statements. Through the site, you can send declarations electronically, and calculate the amount of tax using a tax calculator. The literature details the benefits of the Polish tax portal (Teszner, 2015).

If the powers of local governments to establish and introduce local taxes and charges include powers related to the approval of tax returns and other tax reporting forms, in this case, the municipalities themselves may provide for the possibility of providing such reports in electronic form. For example, in Poland, it is stipulated that in municipalities, where municipal councils, in their decrees, establish the conditions and procedure for submitting information about real estate and construction objects, as well as property tax returns via electronic communication, these documents can be submitted online. The same is true for agricultural tax - you can submit information about land and agricultural tax declarations online in those municipalities that defined the resolution in the resolution of the conditions and procedure for submitting information about the land plot and agricultural tax declarations via electronic communication. The same rules apply for other local taxes (https://www.podatki.gov.pl/podatki-i-oplaty-lokalne/). 
Thus, the interaction between taxpayers and tax authorities is quite effective, including when calculating and paying local taxes. At the same time attention should be paid to the lack of clear information campaign to encourage taxpayers to interact with the tax administration (Teszner, 2015: 188).

The most effective is the use of information and digital technologies in the implementation of control over the payment of taxes, as well as the registration of objects of taxation. First of all, these functions are carried out by tax authorities, but control can also be exercised by state and local authorities.

Since in Russia, property taxes as well as deductions from the personal income tax come mainly to local budgets, it is important for local authorities to increase control over the collection of these taxes. In respect of property taxes, accounting for objects of taxation is in the foreground, since property owners do not always register and target the property, for example, a land plot. The purpose of the land affects the cadastral value of the object and the size of the land tax rate. In practice, there are cases when the land plot is allocated for individual housing construction (taxed at the minimum rate), while in fact the land is used for commercial development, for example, the construction of a hotel.

For example, in Moscow region alone, according to expert estimates, 355 thousand of 8.8 million Moscow real estate objects in the state real estate cadastre do not have areal and extended characteristics, more than 80 thousand land plots do not have the category and type of permitted use, over 1.1 million objects are not registered by citizens and are not taken into account in the tax turnover (Rosreestr attacks from the air ...). Owners of such land plots and capital construction objects owned by individuals do not pay taxes. And these are exactly the taxes that go to the local budget.

Traditional control methods do not always allow timely detection of violations, as well as identification of unregistered property objects for subsequent tax registration. In this regard, some Russian regions began to apply modern technologies to control such objects, for example, to use quadcopters to control taxpayers and their property.

Despite the fact that the legal regulation of the use of unmanned aircraft (quadcopters) currently raises many questions (Anisimov, Ivanova, 2017), nevertheless, quadcopters are successfully used by Russian authorities for control purposes.

The first quadcopters to control the legality of the use of land in the suburbs began to be used in 2014. At the end of 2016, the Ministry of Property Relations of 
Moscow Region involved in circulation 72 thousand land plots that have violations of the law. This increased tax revenues to the budget from 12 billion to 35 billion rubles. (Rosreestr attacks from the air ...). In 2018, the Federal Tax Service of Russia continued the campaign to identify unaccounted property. The results of this campaign will be known in autumn of 2019 when taxpayers receive notices of payment of property taxes.

It should be noted that drones are also used in other European countries to combat tax evasion. Russia's experience is similar to the situation in Spain, where the tax service of Spain using satellites and quadcopters found 1.69 million homes that had discrepancies in the data, for example, there was no information about outbuildings and pools, and in some cases houses were not registered at all. The operation was carried out in 4340 municipalities of Spain. In total, violations were found in $8.9 \%$ of the houses registered in the municipal registries of Spain. 1.3 billion euro of land tax was additionally collected in the budget. (Impuesto sobre Bienes Inmuebles) (Drones hunt down 1.7 million tax cheats in Spain...).

An important issue is the cost of tax administration so that the cost of controlling tax payments does not exceed the cost of taxes collected. The experience of Spain, where 16 euros were raised for every euro spent, shows that the use of drones is effective for tax collection. For Russia, data on the cost of controlling property tax objects using quadcopters is currently not available.

In Greece, tax authorities used drones on the island of Santorini to document tax violations, namely, to collect evidence that the operators of nine tourist boats do not pay taxes. Total evidence collected revealed 145 tax violations amounting to 25,000 euros of lost revenue (Greece uses drones ...).

In tax revenues of local budgets, a large share is a tax on personal income. Local governments do not take part in controlling the payment of this tax; they do not have regulatory powers since this tax is federal. At the same time, municipalities interested in receiving this tax in the budget can identify revenues from which the tax was not paid. Such income should include income from the rental of property, business activities, including unregistered, from wages of employees with whom employment contracts have not been concluded in the prescribed manner, etc. (Gliniecka, Mironova, 2019: 108).

Further development of artificial intelligence can lead to the emergence of programs with the help of which tax authorities or local governments will be able to track information about certain operations (for example, about renting an apart- 
ment on the popular Russian website Avito) and when revealing information in an automatic mode to send a letter to a citizen with a request to provide explanations on this fact. It should be noted that for municipalities these costs will be exorbitant, thus the introduction of such technologies in Russia is more likely to take place at the level of the state program.

If there are more local taxes and charges in the state, it should be assumed that electronic interaction and control over the payment of these payments will be required to a greater extent. For example, the Law of Poland of January 12, 1991 on local taxes and charges establishes such taxes and charges as real estate tax, vehicle tax, trading charge, resort charge, local charge (analogue of the resort charge), advertising charge, charge for keeping dogs. In cases when accounting for objects of taxation is necessary (vehicles, dogs, billboards or advertising structures), electronic interaction between accounting authorities and tax authorities will be more effective.

Drones can also be used by municipalities in order to use budget funds more efficiently, for example, to reduce costs when using quadcopters is cheaper than using other technologies. Numerous foreign examples show this. For example, the use of drones by a local fire department in Plymouth, Massachusetts to examine the extent of damage after winter blizzards; modeling erosion of beaches along the entire stretch of coastline; monitoring of groundwater flow, etc. (Phillipson, 2015). On the one hand, the use of drones will reduce the costs of local budgets. On the other hand, it should be stated that, as a rule, there are no free funds in Russian municipalities, because of their subsidies, and only large municipalities could afford to buy quadcopters. As an alternative to this, we can consider renting drones or allocating transfers from a higher budget for the purchase of drones within the framework of the digitalization of the economy. As an example, the experience of the United States should be cited: for several years now, the Department of National Security has been implementing the "loan under the drone" program, under which it provides drones to local federal law enforcement agencies, as well as municipal institutions (Phillipson, 2014).

The scientific literature raises the question of the ability of municipalities to have their own e-currency. So, In Poland, "local governments are limited to issuing tokens that only function for a certain time, and their function is more to promote and attract tourists than to participate directly in the course of trade" (Cyman, 2018: 520). This is due to insufficient legal regulations regarding the possibility of issuing this money, the conditions that should be met and the related legal risk for 
both the issuer and the people using it. In Russia, there are no examples of such a release of local digital currency, which is determined by the prohibition of legislation on the issuance by municipalities of their currency. At the same time, the issue of cryptocurrency is still not regulated by law in Russia.

\section{Conclusion}

Despite the rapid development of legislation in the field of digital economy, legal regulation is carried out mainly at the national level, and almost does not affect the digitization of the financial activities of municipalities. Despite the fact that egovernment programs, and interactions between government bodies also concern local governments, in practice, due to the lack of financial resources in municipalities, such technologies are being introduced last. Nevertheless, one cannot but recognize the influence of information technologies on improving the quality of work of municipalities, improving the efficiency of their financial activities.

In Russia, for the time being, the standard regulation of digital economy is carried out only at the federal level, separate regulatory acts are being developed at the level of regions and municipalities, but the legal framework has not yet been fully formed. At the same time, the allocation of budget funds for the introduction of information and technologies from the federal budget does not yet extend to support municipalities, since they lack the appropriate legal regulation and municipal programs aimed at introducing digital technologies to solve local issues. At the regional and municipal levels, commissions and coordinating bodies are created for the development of digital economy.

For municipalities, a special role is played by increasing the collection of revenues of local budgets, especially from tax payments. In this regard, it is important to work with taxpayers, both in terms of informing them about tax payments, their tax duties, electronic interaction with tax authorities and local governments (in cases where it is necessary, for example, when registering objects of taxation), obtaining permission to pay the charge, etc.), and in part of the implementation of control over the payment of taxes, both by tax authorities and by state authorities and local governments.

The most effective is the use of information and digital technologies in the implementation of control over the payment of taxes, as well as the registration of objects of taxation. First of all, these functions are carried out by tax authorities, but control can also be exercised by state and local authorities. 
Since one of the main taxes that go to local budgets is property taxes, control over the registration of property objects is of great importance for increasing their collection. Traditional control methods do not always allow timely detection of violations, as well as identification of unregistered property objects for subsequent tax registration. In this regard, some Russian regions, Spain, and Greece began to apply modern technologies to control such objects, for example, to use quadcopters to control taxpayers and their property. Practice shows that the use of quadcopters can be quite effective and can bring additional revenues to local budgets.

Drones can also be used by municipalities in order to use budget funds more efficiently, for example, to reduce costs when using quadcopters is cheaper than using other technologies.

On the one hand, the use of drones will reduce the costs of local budgets. On the other hand, it should be stated that, as a rule, there are no free funds in Russian municipalities, because of their subsidies, and only large municipalities could afford to buy quadcopters. As an alternative to this, we can consider renting drones or allocating transfers from a higher budget for the purchase of drones within the framework of the digitalization of the economy.

\section{References}

Anisimov, A., Ivanova, J.: Pravovoe regulirovanie ispol'zovaniya bespilotnyh vozdushnyh sudov (kvadrokopterov): diskussionnye voprosy (Legal regulation of the use of unmanned aircraft (quadcopters): controversial issues), Vestnik Instituta zakonodatel'stva Respubliki Kazahstan (Bulletin of the Institute of Legislation of the Republic of Kazakhstan) no. 4 (2017).

Cyman, D.: Regional Complementary Currencies as an Element of Regional Policy, in: Mrkývka, P., Gliniecka, J., Tomášková, E., Juchniewicz, E., Sowiński, T., Radvan, M. (eds.): The Challenges of Local Government Financing in the Light of European Union Regional Policy (Conference Proceedings), Brno 2018.

Dowgier, R.: New Polish Codification of General Tax Law and the Needs of Tax Authorities of Local Government Units, in: Radvan, M., Gliniecka, J., Sowiński, T., Mrkývka, P., (eds.): The financial law towards challenges of the XXI century. Conference Proceedings, Masaryk University, Žerotínovonám. 617/9, 60177 Brno, 2017.

Drones hunt down 1.7 million tax cheats in Spain. https://www.thelocal.es/20160726/ spain-uses-drones-to-hunt-tax-evaders

Etel, L.: Municipal Tax Authorities: are Changes Needed?, in: Mrkývka, P., Gliniecka, J., Tomášková, E., Juchniewicz, E., Sowiński, T., Radvan, M. (eds.): The Challenges of Lo- 
cal Government Financing in the Light of European Union Regional Policy (Conference Proceedings), Brno 2018.

Gliniecka, J., Mironova, S.: The sources of financing local government in Poland and Russia: Comparative analysis. Gdansk: Gdańsk University Press, 2019.

Greece uses drones to find tax fraud. https://www.nomoretax.eu/greece-drones-taxfraud/

Juchniewicz, E.: The principle of fiscal local autonomy in the light of Polish Constitution, Financial Law Review no. 2 (2017).

Kranecová, J., Czudek, D.: European Charter of Local Self-Government in the Czech Republic, Financial Law Review no. 2 (2017).

Krokhina, Yu.: Obsluzhivanie schetov byudzhetov: k voprosu o konstitucionnosti sootnosheniya kompetencii Central'nogo banka i kreditnyh organizacij (Maintenance of accounts of budgets: to the question of the constitutionality of the relation of competence of the Central Bank and credit organizations), Finansovoe pravo (Financial law) no. 3 (2005).

Kucherov, I.: Kriptovalyuta kak platezhnoe sredstvo (Cryptocurrency as a means of payment), Finansovoe pravo (Financial law) no. 7 (2018).

Mariański, M.: Challenges and Problems of Local Government Finances in the Light of the French Cour des Comptes Reports as a Guide for the Polish Legislature, in: Mrkývka, P., Gliniecka, J., Tomášková, E., Juchniewicz, E., Sowiński, T., Radvan, M. (eds.): The Challenges of Local Government Financing in the Light of European Union Regional Policy (Conference Proceedings), Brno 2018.

Mikliński, M.: Legal aspects of selected modern methods of payment, Financial Law Review no. 9 (1) (2018).

Mironova, S., Kozlova, M.: Participation of citizens in the financial activities of municipalities: the experience of Russia and other countries, in: Mrkývka, P., Gliniecka, J., Tomášková, E., Juchniewicz, E., Sowiński, T., Radvan, M. (eds.): The Challenges of Local Government Financing in the Light of European Union Regional Policy (Conference Proceedings), Brno 2018.

Mironova, S.: Fiscal Lawmaking Municipalities: The Experience of Russia and European States, in: Sentsova (Karaseva), M., Ruskowski, E., Paul, A., Radvan, M. (eds.): Tax Sovereignty and the Concept of Fiscal Rule-Making in the Countries of Central and Eastern Europe: Conference Proceedings, Voronezh: Voronezh State University, Faculty of Law, 2018.

Mosionek-Schweda, M., Panfil, P.: Principles of Incurring Financial Liabilities by Local Government Units for Tasks Carried out under the Regional Policy of the European Union, in: Mrkývka, P., Gliniecka, J., Tomášková, E., Juchniewicz, E., Sowiński, T., Radvan, M. (eds.): The Challenges of Local Government Financing in the Light of European Union Regional Policy (Conference Proceedings), Brno 2018. 
Pastushenko, E., Zemtsova, L.: Questions of the Central Bank of the Russian Federation Lawmaking in Regard to Banks' Liabilities in the Framework of the Russian Tax Legislation, in: Sentsova (Karaseva), M., Ruskowski, E., Paul, A., Radvan, M. (eds.): Tax Sovereignty and the Concept of Fiscal Rule-Making in the Countries of Central and Eastern Europe: Conference Proceedings, Voronezh: Voronezh State University, Faculty of Law, 2018.

Paul, A.: Realization of Tax Sovereignty in Value-Added Taxation of Cross-Border Transactions, in: Sentsova (Karaseva), M., Ruskowski, E., Paul, A., Radvan, M. (eds.): Tax Sovereignty and the Concept of Fiscal Rule-Making in the Countries of Central and Eastern Europe: Conference Proceedings, Voronezh: Voronezh State University, Faculty of Law, 2018.

Paul, A.; Soloweva, N.: Budget and Tax Legislation of the Russian Federation: Consequences of Contradictions for Sub-Federal Budgets, Financial Law Review no. 1 (1) (2016).

Phillipson, A.: Drones in Law Enforcement. https://dronelife.com/2014/03/17/drones-inlaw-enforcement/

Phillipson, A.: Drone Aircraft Help Save Taxpayer Dollars in Hawaii. https://dronelife. com/2015/04/08/drone-aircraft-help-save-taxpayer-dollars-in-hawaii/

Radvan, M.: Article 9 of the European Charter of Local Self-Government in the Czech Republic, Financial Law Review no. 2 (4) (2017).

Radvan, M.: Electronic Revenue Registry as A Tool for Fair Tax Payments, in: Sentsova (Karaseva), M., Ruskowski, E., Paul, A., Radvan, M. (eds.): Tax Sovereignty and the Concept of Fiscal Rule-Making in the Countries of Central and Eastern Europe: Conference Proceedings, Voronezh: Voronezh State University, Faculty of Law, 2018.

Reut, A., Soloveva, N.: Tax Competence of Local Authorities: Experience of the Russian Federation, in: Mrkývka, P., Gliniecka, J., Tomášková, E., Juchniewicz, E., Sowiński, T., Radvan, M. (eds.): The Challenges of Local Government Financing in the Light of European Union Regional Policy (Conference Proceedings), Brno 2018.

Románova, A., Červená, K.: Current System of Funding of Local Self-Government in Slovakia and its Challenge, Financial Law Review no. 2 (4) (2017).

Schlossberger, O.: Legal Aspects of Electronic Money, in: Blažek J. (ed.): System of Financial Law: Financial Markets: Conference Proceedings, 1st ed., Brno: Masaryk University, Faculty of Law, 2015.

Schweigl, J., Blažek, J.: Monetary Policy in the Twenty-First Century, in: Radvan, M., Gliniecka, J., Sowiński, T., Mrkývka, P. (eds.): The financial law towards challenges of the XXI century: (conference proceedings), 1st ed., Brno: Masaryk University, 2017.

Skuza, S.: Legal conditions limiting fundraising capabilities of local self-government units. Status and original propositions concerning introduction of changes together with Bank Gospodarstwa Krajowego, Financial Law Review no. 2 (3) (2017). 
Sowiński, T.: The process of municipalization of the state in a spirit of the idea of subsidiarity and in accordance with the European charter of local self-government at the example of Poland from 1990 to 2015, Financial Law Review no. 2 (4) (2017).

Teszner, K.: E-tax Administration in the Contemporary Polish System of Financial Law, in Radvan, M. (ed.): System of Financial Law: System of Tax Law: Conference Proceedings, 1st ed., Brno: Masaryk University, Faculty of Law, 2015.

Mihail Mishustin podvel itogi raboty nalogovyh organov za 2018 god (Mikhail Mishustin summed up the work of the tax authorities in 2018). https://www.nalog.ru/rn77/news/ activities_fts/8434593/

Rosreestr atakuet s vozduha (Rosreestr attacks from the air). https://www.gazeta.ru/business/2016/06/06/8288723.shtml 